\title{
IMPLEMENTASI KEBIJAKAN PELATIHAN KEWIRAUSAHAAN BAGI MILLENNIAL ENTREPRENEUR
}

\section{IMPLEMENTATION OF ENTREPRENEURSHIP TRAINING POLICY FOR MILLENNIAL ENTREPRENEUR}

\author{
Untung Supriyanto ${ }^{*}$, Arenawati², Juliannes Cadith ${ }^{3}$ \\ 1,2,3Pascasarjana Magister Administrasi Publik, Universitas Sultan Ageng Tirtayasa, Jl. Raya \\ Jakarta Km 4, Pakupatan, Panancangan, Cipocok Jaya, Kota Serang, Banten 42124 \\ *Korespondensi: Untung Supriyanto. Email: untungpsh@yahoo.co.id
}

(Diterima: 23-12-2020; Ditelaah: 21-01-2021; Disetujui: 03-03-2021)

\begin{abstract}
This research is motivated by the challenge of demographic bonus that the number of productive age population is larger than the number of non productive age population. Based on the reason, this research aims to analyze the implementation of entrepreneurship training policy for millenial entrepreneur conducted by the Local Office of Manpower and Transmigration of Serang Regency. The theory of public policy implementation proposed by Mazmanian and Sabatier (1983) is used as theoretical basis for analyzing the implementation of entrepreneurship training policy for millenial entrepreneur. This research uses a qualitative approach combined by an analytical descriptive method. The results of this research indicate that the entrepreneurship training policy for millenial entrepreneur conducted by the Local Office of Manpower and Transmigration of Serang Regency has been well implemented. Nevertheless, the policy implementation finds the inhibiting factors, namely the mindset and thought of the target group formed by the background of sociocultural conditions. Whereas the supporting factors for improving the implementation of entrepreneurship training policy for millenial entrepreneur in Serang Regency stem from the support, commitment and consistency of the leadership in implementing the policy.
\end{abstract}

Key words: Policy Implementation, Millennial Entrepreneur, Entrepreneurship Training.

\begin{abstract}
ABSTRAK
Penelitian ini dilatarbelakangi oleh tantangan bonus demografi bahwa penduduk usia produktif, termasuk di dalamnya penduduk kelompok milenial, lebih besar jumlahnya dibandingkan dengan jumlah penduduk usia non-produktif. Dengan latar belakang tersebut, penelitian ini bertujuan untuk menganalisis implementasi kebijakan pelatihan kewirausahaan bagi millenial entrepreuner yang dilakukan oleh Dinas Ketenagakerjaan dan Transmigrasi Kabupaten Serang. Teori implementasi kebijakan publik Mazmanian dan Sabatier (1983) digunakan sebagai landasan teori untuk menganalisis implementasi kebijakan pelatihan kewirausahaan bagi millenial entrepreuner. Penelitian ini menggunakan pendekatan kualitatif dengan metode deskriptif analitis. Hasil penelitian menunjukkan bahwa kebijakan pelatihan kewirausahaan bagi millenial entrepeneur yang dilakukan oleh Dinas Ketenagakerjaan dan Transmigrasi Kabupaten Serang telah diimplementasikan dengan baik. Akan tetapi dalam implementasinya ditemukan faktor penghambat yang timbul berupa faktor mindset dan pola pikir kelompok sasaran yang dilatarbelakangi oleh keadaan sosial budaya. Sedangkan faktor pendukung keberhasilan implementasi kebijakan pelatihan kewirausahaan bagi millenial entrepeneur di Kabupaten Serang yang ditemukan dalam penelitian ini bersumber dari dukungan, komitmen dan konsistensi pimpinan dalam melaksanakan kebijakan.
\end{abstract}

Kata kunci: Implementasi Kebijakan, Millenial Entrepreneur, Pelatihan Kewirausahaan.

Supriyanto, Untung; Arenawati \& Cadith, Juliannes. (2021). Implementasi Kebijakan Pelatihan Kewirausahaan Bagi Millennial Entrepreneur. Jurnal GOVERNANSI, 7(1): 39-50. 


\section{PENDAHULUAN}

Penduduk kelompok generasi milenial di Indonesia saat ini diperkirakan sebanyak $34 \%$ dari total penduduk, dan akan semakin besar seiring dengan perkembangannya dan pada masa tahun 2030-2040 mendatang, Indonesia akan menghadapi fenomena bonus demografi, dimana angka jumlah penduduk usia produktif jauh lebih besar dibandingkan dengan penduduk tidak produktif (Lestari, et al., 2021). Hal ini menjadi tantangan tersendiri bagi pemerintah Indonesia, bagaimana agar kondisi tersebut menjadi keuntungan dan senjata bagi Indonesia menghadapi persaingan dengan dunia luar.

Pengangguran menjadi masalah serius di Indonesia yang jelas jelas menghambat upaya Indonesia untuk bersaing dalam era globalisasi. Hampir di seluruh wilayah di Indonesia mengalami permasalahan di bidang ketenagakerjaan, yaitu pengangguran. Salah satunya adalah Kabupaten Serang, yang merupakan penyumbang angka pengangguran tertinggi di Provinsi Banten. Menurut data Badan Pusat Statistik (BPS), penduduk Kabupaten Serang tahun 2019 berjumlah 1.508 .397 jiwa. Jumlah penduduk tersebut dapat dikelompokkan berdasarkan kelompok usia (Tabel 1).

Tabel 1. Penduduk Kabupaten Serang menurut Kelompok Usia Tahun 2019

\begin{tabular}{llcc}
\hline No. & Kelompok Usia & Jumlah (Jiwa) & $\%$ \\
\hline 1 & $\begin{array}{l}\text { Penduduk usia 0- } \\
\text { 14 tahun }\end{array}$ & 445.815 & 29,56 \\
\hline 2 & $\begin{array}{l}\text { Penduduk usia } \\
\text { 15-64 tahun }\end{array}$ & 999.212 & 66,24 \\
\hline 3 & $\begin{array}{l}\text { Penduduk usia } \\
\text { 65 tahun }\end{array}$ & 63.370 & 4,20 \\
\hline & Jumlah & & \\
\hline Sumber: Badan Pusat Statistik Kabupaten Serang (2020)
\end{tabular}

Pada Tabel 1, penduduk Kabupaten Serang berusia 15-64 tahun (usia produktif) lebih banyak jumlahnya dibanding penduduk usia 0-14 tahun (usia muda/tidak produktif) dan penduduk usia $\geq 65$ tahun (usia tua/tidak produktif). Jumlah tersebut menunjukkan jumlah usia produktif yang besar dimana generasi milenial berada di dalam kelompok ini. Kondisi tersebut dapat menjadi keunggulan di satu sisi, namun di sisi lain semakin menunjukkan bahwa pengelolaan generasi millenial untuk dapat menjadi pelaku dalam industri masih belum maksimal. Hal tersebut dapat dikaitkan dengan indikator-indikator ekonomi yang mempengaruhinya seperti tingkat pendidikan, pertumbuhan ekonomi, serta upah. Dalam hal ini, pendidikan diharapkan dapat melahirkan sumber daya manusia yang berkualitas agar dapat memperoleh pekerjaan sesuai dengan jenjang pendidikan yang telah ditempuhnya.

Sampai saat ini pendidikan dan pelatihan bidang kewirausahaan masih dianggap berperan penting dalam memperkuat jiwa kewirausahaan peserta didik. Berbagai literatur memaparkan peran penting pendidikan dan pelatihan bagi tumbuhnya semangat berwirausaha. Berbagai literatur menjelaskan bahwa kepemilikan semangat berwirausaha bukan semata karena faktor bawaan atau keturunan (born) sehingga secara otomatis melekat pada diri seseorang, tetapi dapat dibentuk dan dipersiapkan (made) melalui kegiatan pendidikan dan pelatihan, sehingga seseorang bisa menjadi pewirausaha yang tangguh. Oleh karena itu, hingga saat ini berbagai lembaga pendidikan formal mengajarkan pendidikan kewirausahaan yang dirancang untuk membekali peserta didik agar kelak bisa menjadi pewirausaha yang sukses (Sudarwati, 2018). Namun sangat disayangkan bahwa minat dan motivasi kaum milenial untuk berwirausaha masih rendah.

Di luar jumlah pengangguran yang tinggi, persentase pekerja informal di Kabupaten Serang masih lebih tinggi dibanding pekerja formal. Pada bulan Agustus 2019, pekerja formal tercatat sebanyak 293,62 ribu orang atau sebesar 48,22 persen. Jumlah pekerja informal yang tinggi, jika tidak diarahkan, dibina dan dilatih dengan maksimal, akan rawan menjadi penyumbang angka pengangguran. 
Hal inilah yang diupayakan oleh pemerintah melalui pemerintah daerah Kabupaten Serang, salah satunya adalah dengan dikeluarkannya kebijakan pelatihan kewirausahaan bagi millenial entrepreneur di Kabupaten Serang.

Tumbuh kembang entrepreneur di Kabupaten Serang belum maksimal. Bank Indonesia (BI) mencatat jumlah wirausaha di Indonesia hanya berkisar $0,24 \%$ dari seluruh penduduk Indonesia, jauh di bawah negara-negara berkembang lainnya. Dinas Perindustrian dan Perdagangan Kabupaten Serang pada bulan April 2019 mencatat jumlah UMKM di Kabupaten Serang mencapai 26.919 usaha yang meliputi pedagang, petani, nelayan, dan lainnya (Disperindag, 2019). Namun tidak semua dapat survive menjalankan usahanya, khususnya wirausaha muda. Banyak wirausaha muda kurang terampil dan kurang dapat menghadapi persaingan yang ketat dalam era digital saat ini. Banyak bisnis UMKM yang dimotori oleh entrepreneur muda berhenti di tengah jalan karena berbagai hal.

Permasalahan yang dihadapi oleh pengusaha kecil industri agro di Kabupaten Serang menurut Dinas Koperasi Usaha Mikro Kecil dan Menengah Kabupaten Serang (2009) menyangkut pola tindak pengusaha kecil itu sendiri yang meliputi: (1) masih lemah dalam menekuni usahanya, (2) kurang mampu menjalin hubungan dengan berbagai pihak terkait usahanya, (3) kurang mampu membaca peluang, (4) kelemahan dalam mengakses dan persaingan pasar, serta (5) keterbatasan akses ke lembaga-lembaga keuangan. Sehingga perlu dirumuskan lagi upaya pengembangan dan pelatihan entrepreneur muda di Kabupaten Serang, agar benar-benar dapat menjadi solusi yang efektif dalam rangka pengentasan angka pengangguran yang masih tinggi. Permasalahan lain yang juga menjadi kendala adalah kapasitas Balai Latihan Kerja yang masih kurang, metode pelatihan yang tidak sesuai dengan kebutuhan di lapangan, dan sarana prasarana pelatihan di BLK yang kurang memadai.

\section{MATERI DAN METODE}

\section{Kebijakan Publik}

Istilah kebijakan publik (public policy) secara umum dipergunakan untuk menunjuk perilaku seseorang atau sekelompok orang atau suatu institusi seperti seorang pejabat, suatu kelompok, maupun suatu lembaga pemerintah dalam suatu bidang kegiatan tertentu. Eyestone (1971) dalam Wahab (2012: 13) mengemukakan bahwa secara luas kebijakan publik dapat didefinisikan sebagai hubungan suatu unit pemerintah dengan lingkungannya. Edward III (1980) dan Sharkansky (dalam Islamy, 1984: 18) menegaskan bahwa kebijakan publik adalah what government say and do, or not to do. It is the goals or purpose of government programs, (apa yang pemerintah katakan dan lakukan, atau tidak lakukan. Kebijakan merupakan serangkaian tujuan atau sasaran dari program-program pemerintah).

Dari beberapa pendapat tersebut di atas dapat disimpulkan bahwa kebijakan publik merupakan serangkaian pilihan untuk berbuat ataupun tidak berbuat sesuatu yang mengakibatkan terjadinya persentuhan antara pemerintah dengan rakyatnya yang di dalamnya terkandung unsur-unsur seperti tujuan yang luas dan sasaran yang spesifik serta cara untuk mencapai sasaran yang telah dirumuskan oleh badan atau kantor pemerintah.

\section{Implementasi Kebijakan Publik}

Van Meter dan Van Horn (dalam Budi Winarno, 2008: 146-147) mendefinisikan implementasi kebijakan publik sebagai tindakan-tindakan dalam keputusankeputusan sebelumnya. Tindakan-tindakan ini mencakup usaha-usaha untuk mengubah sebuah keputusan menjadi tindakantindakan operasional dalam kurun waktu tertentu maupun dalam rangka melanjutkan usaha-usaha untuk mencapai perubahan besar dan kecil yang ditetapkan oleh keputusan-keputusan kebijakan yang dilakukan oleh organisasi publik yang 
diarahkan untuk mencapai tujuan yang telah ditetapkan.

Mazmanian dan Sabatier (1979) dalam Wahab (2012: 135) mengemukakan bahwa implementasi dapat diartikan sebagai sesuatu untuk memahami apa yang senyatanya terjadi sesudah suatu program dinyatakan berlaku atau dirumuskan. Lebih lanjut ditegaskannya bahwa implementasi adalah pelaksanaan keputusan kebijakan dasar, biasanya dalam bentuk undangundang, namun dapat pula berbentuk perintah-perintah atau keputusankeputusan eksekutif yang penting atau keputusan badan peradilan.

Mazmanian \& Sabatier menyebutkan variabel-variabel yang mempengaruhi keberhasilan implementasi kebijakan, yaitu mudah-tidaknya masalah yang digarap, kemampuan kebijakan menstruktur proses implementasi secara tepat dan faktor-faktor di luar kebijakan yang mempengaruhi implementasi. Model implementasi kebijakan yang dikemukakan oleh Mazmanian dan Sabatier disebut dengan a framework for policy implementation analysis. Model ini berpendapat bahwa peran penting dari implementasi kebijakan publik adalah kemampuannya dalam mengidentifikasikan variabel-variabel yang mempengaruhi tercapainya tujuan-tujuan formal pada keseluruhan proses implementasi.

\section{Millenial Enterpreneur}

Generasi milenial atau dikenal dengan generasi $\mathrm{Y}$ atau generasi langgas (SWA, 2017) merupakan kelompok demografi yang muncul setelah generasi X. Generasi ini adalah kelompok generasi yang lahir antara tahun 1980-an sampai dengan tahun 1990an. Dengan demikian, generasi millennial adalah generasi muda yang sekarang berusia antara 17-37 tahun. Tidak dapat dielakkan, kelompok generasi inilah yang mulai sekarang akan banyak mengisi dan berwarnai corak kehidupan masyarakat jaman now dan kehidupan masyarakat pada masa yang akan datang. Generasi millennial inilah yang akan menentukan apakah bangsa kita akan mampu tampil setara dan mampu bersaing dengan bangsa lain dalam komunitas global.

Kelompok generasi millenial dalam kehidupannya selalu mengandalkan kecepatan, dan cenderung suka pada hal-hal yang serba instan. Hasil riset yang dirilis oleh Pew Riset Centre menjelaskan keunikan generasi millennial yang tidak bisa dilepaskan dari keberadaan teknologi internet dan budaya pop. Generasi millennial memiliki ketergantungan yang sangat tinggi dengan teknologi internet. Mereka juga lebih terbuka dengan berbagai ide baru dan gagasan dari sumber manapun.

Secara etimologi, entrepreneur berasal dari Bahasa Perancis, entreprendre yang artiya berusaha. Dikenal mulai abad ke 17. Sedangkan secara terminologi, entrepreneur atau kadang disebut entrepreneurship secara istilah adalah suatu disiplin ilmu yang mempelajari nilai, kemampuan dan perilaku seseorang dalam menghadapi tantangan hidup untuk memperoleh peluang dengan berbagai risiko yang dihadapinya. Dengan demikian dapat dikatakan bahwa milenial entrepreneur adalah kelompok generasi milenial yang berusaha untuk mengatasi tantangan dengan mengoptimalkan potensi dan peluang yang ada dalam kehidupan.

\section{Konsep Pelatihan Kewirausahaan}

Kewirausahaan: Kewirausahaan (entrepreneurship) dapat dimaknai sebagai jiwa, semangat, sikap, perilaku, dan potensi kemampuan seseorang dalam menangani usaha dan atau kegiatan yang mengarah pada upaya mencari, menciptakan, menerapkan cara kerja, teknologi, dan produk baru dengan meningkatkan efisiensi dalam rangka memberikan pelayanan yang lebih baik untuk memperoleh keuntungan yang lebih besar" (Subijanto, 2012: 165).

Dalam implementasi program pendidikan kewirausahaan terdapat dua kebijakan terkait dengan kewirausahaan 
(Depdiknas, 2010), yaitu kewirausahaan sebagai mata pelajaran di tingkat pendidikan menengah, dan sebagai mata kuliah pada jenjang pendidikan tinggi, serta kewirausahaan sebagai keahlian yang mengacu pada standar kompetensi. Karakter wirausaha terbagi menjadi tiga dimensi, yaitu mindset, hearthset dan actionset (Dharma, 2009: 9). Dengan demikian, pendidikan karakter kewirusahaan merupakan pendidikan dasar yang membangun pribadi seseorang dalam proses kewirausahaan, terdiri dari moral knowing, moral feeling, dan moral action.

Pelatihan Kewirausahaan pada Pendidikan Menengah: Pendidikan kewirausahaan di Indonesia lebih dipusatkan pada Pendidikan di Sekolah Menengah Kejuruan. Dicantumkan dalam Peraturan Presiden Nomor 5 Tahun 2010 tentang Rencana Pembangunan Jangka Menengah Nasional 2010-2014, bahwa pembangunan bidang pendidikan diarahkan demi tercapainya pertumbuhan ekonomi yang didukung keselarasan antar ketersediaan tenaga terdidik dengan kemampuan menciptakan lapangan kerja atau kewirausahaan dan menjawab tantangan kebutuhan tenaga kerja.

Pelaksanaan pendidikan karakter dan budaya di Sekolah Menegah Kejuruan menurut Pusat Kurikulum Balitbang Kementerian Pendidikan Nasional dapat dilaksanakan dengan menanamkan pendidikan kewirausahaan ke dalam semua mata pelajaran, bahan ajar, ekstrakurikuler, dan pengembangan diri, mengembangkan kurikulum pendidikan yang memberikan muatan pendidikan kewirausahaan dan menumbuhkan budaya berwirausaha di lingkungan sekolah melalui kultur sekolah. (Endang, dkk, 2010).

Pelatihan Kewirausahaan pada Perguruan Tinggi: Program kewirausahaan yang dapat dilakukan di perguruan tinggi dalam mempersiapkan para lulusan sebagai calon wirausaha baru, yaitu Program Mahasiswa Wirausaha (PMW), Program Magang Kewirausahaan (MKU) dan Program Kuliah Kewirausahaan (KWU). Dalam upaya mewujudkan program tersebut, setiap perguruan tinggi diharapkan mampu: (1) meningkatkan pemahaman dan penjiwaan kewirausahaan di kalangan mahasiswa agar mampu menjadi wirausahawan yang berwawasan jauh ke depan dan luas berbasis ilmu yang diperolehnya; (2) mengenal pola berpikir wirausaha serta meningkatkan pemahaman manajemen (organisasi, produksi, keuangan dan pemasaran); dan (3) memperkenalkan cara melakukan akses informasi dan pasar serta teknologi, cara pembentukan kemitraan usaha, strategi dan etika bisnis, serta pembuatan rencana bisnis atau studi kelayakan yang diperlukan mahasiswa agar lebih siap dalam pengelolaan usaha yang sedang akan dilaksanakan (Ditjen Dikti, 2010).

\section{Kerangka Pemikiran}

Penelitian ini menganalisis bagaimana proses kebijakan Pelatihan Kewirausahaan Millenial Enterpreneur yang diselenggarakan oleh Disnakertrans Kabupaten Serang, dengan memperhatikan faktor faktor yang mempengaruhi, sehingga menghasilkan output yang maksimal, yaitu mengentaskan pengangguran di Kabupaten Serang.

Keberhasilan Implementasi kebijakan pendampingan dan pelatihan kewirausahaan dipengaruhi oleh berbagai faktor, seperti yang diungkapkan oleh Mazmanian \& Sabatier dalam model yang disebut $a$ framework for policy implementation analysis, yaitu faktor mudah-tidaknya masalah yang digarap, kemampuan kebi-jakan menstruktur proses implementasi secara tepat dan faktor-faktor di luar kebijakan yang mempengaruhi implementasi. Faktorfaktor tersebut dilihat dari sudut pandang tiga unsur implementasi kebijakan, yaitu pemrakarsa kebijakan/ pembuat kebijakan (the center atau pusat), pejabat-pejabat pelaksana di lapangan (the periphery atau pinggiran), dan aktor-aktor perorangan di luar badan-badan pemerintahan kepada siapa program itu di ditujukan, yakni kelompok sasaran (target group). 
Konsep implementasi kebijakan publik pada penelitian ini ditentukan oleh tiga parameter, yaitu:

1. Mudah-tidaknya masalah, ditentukan oleh indikator kesulitan-kesulitan teknis kebijakan, keberagaman perilaku petugas, keberagaman perilaku peserta, tingkat perubahan perilaku petugas yang dikehendaki, dan tingkat perubahan perilaku peserta yang dikehendaki.

2. Kemampuan kebijakan, ditentukan oleh indikator kejelasan dan konsistensi tujuan, ketepatan alokasi sumber dana, keterpaduan hirarki antara lembaga, aturan keputusan dari badan pelaksana, rekruitment pejabat pelaksana, dan akses formal pihak luar.

3. Faktor di luar kebijakan, ditentukan oleh indikator kondisi sosial-ekonomi dan teknologi, dukungan publik, sikap dan sumber yang dimiliki kelompok sasaran, dukungan dari pejabat atasan dan komitmen dan kemampuan kepemimpinan pejabat pelaksana.

Solusi yang dianggap tepat untuk mengatasi jumlah pengangguran usia produktif adalah dengan pengalihan orientasi bekerja pada generasi muda atau millennial, yang semula berorientasi pada pekerjaan formal di perusahaanperusahaan, ke arah orientasi bisnis atau entrepreneur, sehingga dapat menciptakan lapangan pekerjaan dan tentu saja akan mengurangi angka pengangguran terbuka. Dengan memperhatikan faktor-faktor implementasi kebijakan, maka strategi pelatihan kewirausahaan akan efektif meningkatkan skill wirausaha pada millennial entrepreneur, yang akan mengalihkan orientasi kerja masyarakat usia produktif, dan pada gilirannya akan mengurangi angka pengangguran terbuka di Kabupaten Serang.

Kerangka pemikiran pada penelitian ini digambarkan sebagaimana terdapat pada Gambar 1.

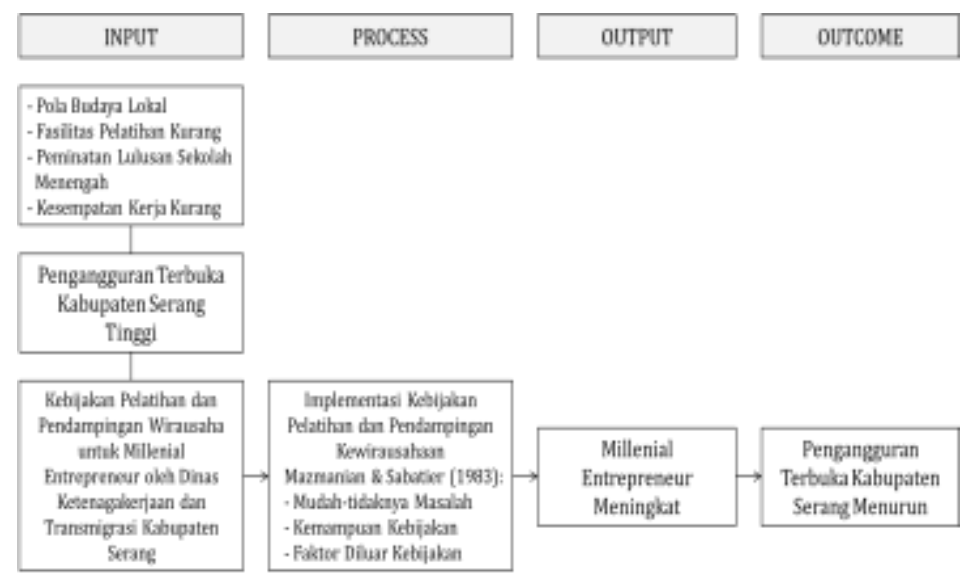

Gambar 1. Kerangka Pemikiran Penelitian

\section{Metode Penelitian}

Penelitian ini menggunakan pendekatan kualitatif dengan metode deskriptif analitis. Data yang digunakan merupakan data primer dan data sekunder, yang diperoleh melalui teknik wawancara, observasi dan dokumentasi. Pada penelitian ini, peneliti berfungsi sebagai instrumen utama yang terjun ke lapangan serta berusaha untuk mendapatkan dan mengumpulkan data dan informasi, selain panduan wawancara dan observasi. Teknik ini dilakukan secara bertahap dan terintegrasi.

Populasi dalam penelitian ini terdiri dari Dinas Ketenagakerjaan dan Transmigrasi Kabupaten Serang sebagai organisasi perangkat daerah yang diberikan wewenang untuk melaksanakan program pelatihan kewirausahaan. Namun untuk mendapatkan informasi menyeluruh, penelitian dilakukan terhadap berbagai unsur yang terkait dengan kebijakan, yaitu unsur dinas terkait yaitu Dinas Ketenagakerjaan dan Transmigrasi Kabupaten Serang, Dinas Perindustrian, Perdagangan dan Koperasi Kabupaten Serang, unsur Balai Latihan Kerja yaitu BBPLK (Balai Besar Pengembangan Latihan Kerja), unsur Bursa Kerja Khusus, unsur Organisasi Masyarakat yaitu HIPPI dan HIPMI Kabupaten Serang, dan unsur kelompok sasaran yaitu peserta pelatihan.

Berdasarkan populasi tersebut, peneliti kemudian menentukan informan- 
informan penelitian. Informan-informan penelitian terdiri dari orang-orang yang terkait baik langsung maupun tidak langsung dalam pelaksanaan kebijakan pelatihan kewirausahaan bagi millenial entrepreneur di Kabupaten Serang. Untuk memperoleh data/informasi penelitian, peneliti mewawancarai 14 informan, dengan informan kuncinya adalah Kepala Dinas Ketenagakerjaan dan Transmigrasi Kabupaten Serang (Tabel 2).

Tabel 2. Tabel Informan/Sumber Data Penelitian

\begin{tabular}{|c|c|c|c|}
\hline $\begin{array}{l}\text { Sumber } \\
\text { Informasi }\end{array}$ & Informan & Nama & Jlh \\
\hline \multirow{4}{*}{$\begin{array}{l}\text { Dinas } \\
\text { Ketenagakerjaan } \\
\text { dan } \\
\text { Transmigrasi } \\
\text { Kabupaten } \\
\text { Serang }\end{array}$} & Kepala Dinas & $\begin{array}{l}\text { H. R. } \\
\text { Setiawan }\end{array}$ & 1 \\
\hline & $\begin{array}{l}\text { Kepala Bidang } \\
\text { Pelatihan dan } \\
\text { Produktivitas }\end{array}$ & Sutarya & 1 \\
\hline & $\begin{array}{l}\text { Kepala Bidang } \\
\text { Pembinaan } \\
\text { dan } \\
\text { Penempatan } \\
\text { Tenaga Kerja } \\
\end{array}$ & Ugun & 1 \\
\hline & $\begin{array}{l}\text { Kepala Seksi } \\
\text { Pelatihan }\end{array}$ & $\begin{array}{l}\text { Didi } \\
\text { Rosadi } \\
\end{array}$ & 1 \\
\hline \multirow{3}{*}{$\begin{array}{l}\text { Dinas } \\
\text { Perindustrian, } \\
\text { Perdagangan } \\
\text { dan Koperasi } \\
\text { Kabupaten } \\
\text { Serang }\end{array}$} & $\begin{array}{l}\text { Sekretaris } \\
\text { Dinas }\end{array}$ & Dedi Arif & 1 \\
\hline & $\begin{array}{l}\text { Kepala Bidang } \\
\text { UMK }\end{array}$ & $\begin{array}{l}\text { Vita } \\
\text { Agustina }\end{array}$ & 1 \\
\hline & $\begin{array}{l}\text { Kepala Bidang } \\
\text { Industri }\end{array}$ & Hudan & 1 \\
\hline $\begin{array}{l}\text { Unsur Balai } \\
\text { Latihan Kerja }\end{array}$ & $\begin{array}{l}\text { Kepala Bidang } \\
\text { Balai Besar } \\
\text { Pengembangan } \\
\text { Latihan Kerja }\end{array}$ & Suyekto & 1 \\
\hline $\begin{array}{l}\text { Bursa Kerja } \\
\text { Khusus SMK } \\
\text { Kabupaten } \\
\text { Serang }\end{array}$ & $\begin{array}{l}\text { Ketua Bursa } \\
\text { Kerja Khusus } \\
\text { SMK } \\
\text { Kabupaten } \\
\text { Serang }\end{array}$ & $\begin{array}{l}\text { Rini } \\
\text { Mutiara }\end{array}$ & 1 \\
\hline \multirow{2}{*}{$\begin{array}{l}\text { Unsur } \\
\text { Organisasi } \\
\text { Masyarakat } \\
\text { Kabupaten } \\
\text { Serang }\end{array}$} & $\begin{array}{l}\text { Pengurus } \\
\text { HIPPI }\end{array}$ & Ifan & 1 \\
\hline & Anggota HIPMI & & 1 \\
\hline $\begin{array}{l}\text { Unsur Kelompok } \\
\text { Sasaran }\end{array}$ & $\begin{array}{l}\text { Peserta } \\
\text { Pelatihan }\end{array}$ & $\begin{array}{l}\text { A. } \\
\text { Tarmidzi } \\
\text { Aditya } \\
\text { Putra }\end{array}$ & 3 \\
\hline Jumlah & & & 14 \\
\hline
\end{tabular}

Sumber: Data Penelitian (2020)

Untuk menilai validitas data data pada penelitian kualitatif, digunakan teknik triangulasi data dan teknik pemeriksaan sejawat melalui diskusi. Analisis data pada penelitian ini menggunakan pendekatan yang dikembangkan oleh Miles \& Huberman (1992) yang dikenal dengan analisis model interaktif, yang terdiri dari empat proses, yaitu pengumpulan data, reduksi data, penyajian data dan penarikan kesimpulan.

\section{HASIL DAN PEMBAHASAN}

\section{Implementasi Kebijakan Pelatihan Kewirausahaan untuk Millenial Entre- preneur}

Kebijakan pelaksanaan pelatihan kewirausahaan untuk millennial entrepreneur dilakukan oleh pemerintah daerah berdasarkan pada Undang-Undang Dasar Negara Republik Indonesia Pasal 18 ayat (6) tentang otonomi daerah, UndangUndang Nomor 20 Tahun 2008 tentang Usaha Mikro, Kecil dan Menengah, Peraturan Pemerintah Nomor 17 Tahun 2013 tentang Pelaksanaan Undang-Undang Nomor 20 Tahun 2008 tentang Usaha Mikro Kecil dan Menengah, ditindaklanjuti dengan peraturan-peraturan di tingkat daerah kabupaten.

Pemerintah Kabupaten Serang telah menerbitkan Peraturan Daerah Kabupaten Serang Nomor 08 tahun 2015 tentang Usaha Mikro Dan Kecil Di Kabupaten Serang, yang salah satu isinya memuat tentang pembinaan dan pengendalian Usaha Mikro dan Kecil, termaktub dalam pasal 33 ayat (1) yang berbunyi: "Pemerintah Daerah melalui SKPD melakukan pembinaan bagi Usaha Mikro dan Kecil dengan kegiatan bimbingan teknis, pelatihan, sosialisasi peraturan, dan workshop". Kebijakan ini menjadi dasar hukum bagi pelaksanaan pelatihan kewirausahaan untuk millennial entrepreneur di Kabupaten Serang.

Kebijakan tersebut kemudian ditindaklanjuti oleh Dinas Ketenagakerjaan dan Transmigrasi Kabupaten Serang sebagai organisasi perangkat daerah yang terkait dengan UMK, dengan program pelatihan terhadap wirausaha oleh Dinas 
Ketenagakerjaan dan Transmigrasi Kabupaten Serang dengan melakukan pelatihan berbasis masyarakat yang diselenggarakan di desa/kecamatan yang tujuannya adalah mengarahkan peserta pelatihan untuk berwirausaha.

Kebijakan yang telah berlaku sebagai dasar pelaksanaan teknis seharusnya memiliki kemampuan untuk menstrukturisasi proses implementasi secara tepat. Salah satu faktor yang menentukan efektifitas suatu kebijakan adalah kemampuan kebijakan dalam menstrukturisasi proses implementasinya, sebagaimana dikemukakan oleh Mazmanian \& Sabatier (1983). Pada kenyataannya di lapangan, Kejelasan dan konsistensi tujuan, sumber dana, keterpaduan hirarki antar lembaga, keputusan dari pelaksana, rekruitment pejabat pelaksana, dan akses formal pihak luar dalam kebijakan yang menjadi dasar pelaksanaan program pelatihan millenial entrepreneur di Kabupaten Serang belum seluruhnya dapat dipenuhi secara maksimal.

Kondisi masyarakat Kabupaten Serang dengan kultur perilaku generasi muda yang kurang terbuka pada perkembangan dan pentingnya entrepreneurship dalam pembangunan ekonomi. Dalam penelitian juga ditemukan bahwa pembelajaran pada Sekolah Menengah di Kabupaten Serang belum sepenuhnya merujuk pada pola pembelajaran yang berbasis entrepreneurship. Pola generasi pikir millenial yang tidak akomodatif dan pola pembelajaran pendidikan menengah yang belum berbasis kompetensi entrepreneur, menjadikan potensi masalah yang cukup besar dalam pelatihan pada millenial enterpreneur di Kabupaten Serang. Sesuai dengan teori yang dikemukakan oleh Mazmanian \& Sabatier (1983), implementasi kebijakan pelatihan kewirausahaan untuk millenial entrepeneur di Kabupaten Serang sangat dipengaruhi oleh faktor mudah-tidaknya masalah digarap.

Program pendampingan terhadap wirausaha muda oleh Dinas Ketenaga- kerjaan dan Transmigrasi Kabupaten Serang juga dilakukan dengan pelatihan masyarakat, dengan konten pelatihan yang dilaksanakan dari mulai dasar keterampilan wirausaha sampai dengan pemasaran. Program pendampingan sebagai lanjutan dari pelatihan masyarakat yang dilakukan oleh Bidang Pembinaan Dinas Ketenagakerjaan dan Transmigrasi Kabupaten Serang merupakan program yang digagas oleh Kementerian Ketenagakerjaan Republik Indonesia, sehingga pembiayaan pun ditanggung oleh Kementerian Ketenagakerjaan melalui Dinas Ketenagakerjaan dan Transmigrasi Kabupaten Serang. Sementara penanganan pelatihan kewirausahaan untuk wirausaha yang telah memiliki usaha, ditanganai oleh organisasi perangkat daerah lain, yaitu Dinas Perdagangan, Perindustrian dan Koperasi Kabupaten Serang.

Dengan demikian dapat disimpulkan bahwa penyelenggaraan pelatihan millenial entrepreneur di Kabupaten Serang dilakukan oleh beberapa Instansi secara bersinergi. Untuk Dinas Ketenagakerjaan dan Transmigrasi Kabupaten Serang sebagai lokus penelitian, program pelatihan millenial entrepreneur berada di bawah koordinasi Bidang Pelatihan dan Produktivitas, dengan alur kebijakan berdasar pada kebijakan yang dikeluarkan oleh Dinas Ketenagakerjaan Provinsi Banten, dan Pemerintah Kabupaten Serang. Sedangkan program pendampingan dilakukan di bawah koordinasi Bidang Pembinaan dan Penempatan Tenaga Kerja terkonsentrasi pada Seksi Perluasan Kesempatan Kerja, dengan alur kebijakan berdasar pada kebijakan pusat, yaitu Kementerian Ketenagakerjaan Republik Indonesia.

Alur kebijakan tersebut khususnya terkait dengan pembiayaan program, sumber dana pembiayaan program pelatihan millenial entrepeneur berasal dari dua sumber yaitu APBD dan APBN. Untuk dana yang berasal dari APBD dikelola oleh Bidang LATAS Dinas Ketenagakerjaan dan Transmigrasi Kabupaten Serang Bidang 
Pelatihan yang bersifat kompetensi industri, dan pelatihan kemasyarakatan, sedangkan dana yang berasal dari APBN, dikelola oleh Bidang BINA PENTA Dinas Ketenagakerjaan dan Transmigrasi Kabupaten Serang untuk pelatihan bersifat kewirausahaan atau pelatihan tenaga kerja mandiri.

Berhasilnya suatu kebijakan dimplementasikan dalam masyarakat, juga ditentukan oleh faktor eksternal kebijakan yang mencakup kondisi sosial-ekonomi dan teknologi, dukungan publik, dukungan dari pejabat atasan dan komitmen kepemimpinan dari pejabat pelaksana. Dalam pelaksanaan program pelatihan Millenial Entrepeneur di Kabupaten Serang, pemerintah memberikan duungan yang cukup, baik dalam hal alokasi dana maupun dukungan kebijakan, namun kondisi sosial terkait kultur dan pola pikir harus dapat perhatian lebih dari pemerintah.

Faktor-faktor yang Menghambat dan Mendukung Implementasi Kebijakan Pelatihan Kewirausahaan untuk Millenial Entrepeneur

Efektifitas implementasi kebijakan pada penelitian ini diukur dengan menggunakan teori yang dikemukakan oleh Mazmanian \& Sabatier (1983), faktor faktor yang mempengaruhi efektifitas implementasi kebijakan menurut Mazmanian Sabatier adalah mudah-tidaknya masalah yang digarap, kemampuan kebijakan menstruktur proses implementasi secara tepat, dan faktor-faktor di luar kebijakan yang mempengaruhi implementasi. Berdasarkan konsep tersebut, maka peneliti melihat bagaimana keberhasilan implementasi kebijakan pelatihan millenial entrepreneur di Kabupaten Serang dengan penelitian pada Dinas Ketenagakerjaan dan Transmigrasi Kabupaten Serang dengan mengidentifikasi faktor-faktor yang mempengaruhi implementasi kebijakan pelatihan kewirausahaan untuk millenial entrepreneur, yaitu:
1. Adapun faktor mudah-tidaknya masalah yang digarap meliputi: (a) kesulitan kesulitan teknis, (b) keberagaman perilaku petugas, (c) keberagaman perilaku kelompok sasaran, serta (d) tingkat perubahan perilaku petugas dan peserta.

2. Sementara faktor kemampuan kebijakan menstruktur proses kebijakan meliputi: (a) kejelasan dan konsistensi tujuan, (b) ketepatan alokasi sumber dana, (c) keterpaduan hirarki antar lembaga, (d) aturan keputusan dari badan pelaksana, (e) rekruitment pejabat pelaksana, dan (f) akses formal pihak luar.

3. Sedangkan faktor eksternal kebijakan mencakup: (a) kondisi sosial-ekonomi dan teknologi, (b) dukungan publik, (c) sikap dan sumber kelompok sasaran, (d) dukungan dari pejabat atasan, dan (e) komitmen kemampuan kepemimpinan pejabat pelaksana.

Pelaksanaan kebijakan pelatihan wirausaha muda tidak terlepas dari hambatan dan dukungan. Hambatan pelaksanaan pelatihan wirausaha muda diantaranya terkait dengan regulasi, yang dianggap terlambat diundangkan, yang berdampak pada pembiayaan. Kendala lain yang didapati dalam penelitian lapangan ini adalah kendala mindset atau pola pikir sasaran kebijakan, yaitu wirausaha pemula atau calon wirausaha. Setelah dianalisis dengan menggunakasn teknis triangulasi, di dapat hasil bahwa mindset sasaran kebijakan, yaitu para pemuda yang diharapkan menjadi millenial entrepreneur masih rendah dan menghambat pengembangan entrepreneur di Kabupaten Serang. Kendala lain yang ditemukan dalam penelitian ini, adalah sosialisasi terkait program kebijakan pelatihan millenial entrepreneur yang masih kurang.

Di luar dari faktor penghambat, dianalisis juga faktor pendukung implementasi kebijakan pelatihan kewirausahaan bagi millenial entreprenenur di 
Kabupaten Serang, yaitu dukungan dari pejabat atasan, dalam hal ini adalah kepala daerah atau Bupati, dukungan tersebut diwujudkan dalam bentuk apresiasi terhadap kegiatan kegiatan yang dilakukan oleh dinas dinas terkait dengan program pelatihan kewirausahaan bagi millenial entrepreneur di Kabupaten Serang, juga alokasi biaya APBD Kabupaten Serang untuk pengembangan kewirausahaan bagi millenial entreprenenur.

\section{KESIMPULAN DAN IMPLIKASI}

\section{Kesimpulan}

Secara umum dapat disimpulkan bahwa kebijakan pelatihan kewirausahaan untuk millenial entrepreneur yang dilakukan oleh Dinas Ketenagakerjaan dan Transmigrasi Kabupaten Serang telah diimplementasikan dengan baik, hanya perlu beberapa inovasi dan upaya maksimalisasi di beberapa segi. Dukungan pejabat pimpinan yang telah baik harus dipertahankan dan terus ditingkatkan, serta harus segera dirumuskan strategi untuk mengubah pola pikir atau mindset dari masyarakat khususnya usia muda sebagai kelompok sasaran sehingga lebih terbuka untuk menjadi millenial entrepreneur daripada menjadi pegawai.

\section{Implikasi}

Implikasi teoritis pada penelitian ini adalah mengkonfirmasi efektifitas implementasi kebijakan yang dapat diketahui dengan menganalisis faktor-faktor yang mempengaruhinya, yaitu faktor mudahtidaknya masalah yang ditangani, faktor kemampuan kebijakan dan faktor di luar kebijakan.

Implikasi kebijakan pada penelitian ini mengkonfirmasi bahwa implementator kebijakan yaitu Dinas Ketenagakerjaan dan Transmigrasi Kabupaten Serang harus menaruh perhatian yang besar terhadap pendidikan entrepreneneur muda, dimulai dari tingkat pendidikan yang paling rendah, karena pola pikir generasi muda yang kurang terbuka terhadap entreprenership ternyata menjadi hambatan terbesar dalam keberhasilan implementasi kebijakan pelatihan kewirausahaan bagi millenial entrepreneur.

\section{Keterbatasan Penelitian dan Rekomen- dasi Penelitian Lanjutan}

Penelitian ini dilakukan dengan menggunakan pendekatan kualitatif dan hanya menganalisis efektifitas implementasi kebijakan pelatihan kewirausahaan bagi millenial entrepreneur pada Dinas Ketenagakerjaan dan Transmigrasi Kabupaten Serang.

Penelitian lanjutan ditujukan untuk melihat bagaimana implementasi kebijakan pelatihan kewirausahaan bagi millenial entrepreneur pada organisasi pemerintah daerah lainnya dan dilakukan dengan pendekatan kuantitatif untuk dapat melihat besarnya pengaruh faktor-faktor penghambat dan pendukung terhadap keberhasilan implementasi kebijakan pelatihan kewirausahaan bagi millenial entrepreneur.

\section{DAFTAR PUSTAKA}

\section{Buku}

Agustino, Leo. (2012). Dasar-dasar Kebijakan Publik. Bandung: CV. Alfabeta.

Bagoes Mantra, Ida. (2003). Demografi Umum. Yogyakarta: Pustaka Pelajar.

Dunn, William N. (1998). Pengantar Analisis Kebijakan Publik. Muhadjir Darwin (Penyunting). Yogyakarta: Gadjah Mada University Press.

Goggin, Malcolm L et al. (1990). Implementation, Theory and Practice: Toward a Third Generation. Scott, Foresmann and Company, USA

Grindle, Merilee. S, (ed). (1989). Politics and Apolicy Implementation in the Third World. New Jersey: Princetown University Press. 
Hoogerwerf. (1983). Ilmu Pemerintahan. Cetakan Pertama. Jakarta: Erlangga.

LAN RI. (2011). Sistem Administrasi Negara Kesatuan Republik Indonesia. Jakarta: Lembaga Administrasi Negara Republik Indonesia.

Lexy J. Moleong. (2012). Metodologi Penelitan Kualitatif. Edisi Revisi. Bandung: PT Remaja Rosdakarya.

Mazmanian, Daniel H., dan Paul A. Sabatier. (1983). Implementation and Public Policy. New York: HarperCollins.

Miles, Mathew B. dan Huberman, A. Michael. (1992). Analisis Data Kualitatif. Diterjemahkan oleh: Tjetjep Rohedi Rosidi. Jakarta: Penerbit Universitas Indonesia.

Moleong, Lexy J. (2000). Metodologi Penelitian Kualitatif. Bandung: PT. Remaja Rosdakarya.

Putra, Fadilah. (2001). Paradigma Kritis dalam Studi Kebijakan Publik. Yogyakarta: Pustaka Pelajar.

Robins, Stelphen P. dan Coulter, Mary. (2010). Manajemen. Edisi Sepuluh. Jakarta: Erlangga.

Rusdiana, (n.d.). Kewirausahaan Teori dan Praktik. Retrieved from http://digilib. uinsgd.ac.id/8783/1/BukuKewirausahaanTeoridanPraktek.pdf.

Subarsono, A. G. (2006). Analisis Kebijakan Publik: Konsep, Teori dan Aplikasi. Yogyakarta: Pustaka Pelajar.

Sugiyono. (2011). Metode Penelitian Kuantitatif dan Kualitatif. Bandung: Alfabeta.

Tachjan. (2008). Implementasi Kebijakan Publik. Bandung: Alfabeta.

Thoha, Miftah. (2008). Ilmu Administrasi Publik Kontemporer. Prenada Media Group.

Wahab, S. (2012). Analisis Kebijakasanaan: Dari formulasi ke Implementasi Kebijakan Negara. Jakarta: Bumi Aksara.
Winarno, Budi. (2002). Teori dan Proses Kebijakan Publik. Yogyakarta: Media Pressindo.

\section{Jurnal}

Berkup, Sezin Baysal. (2014). "Working with Generations $\mathrm{X}$ and $\mathrm{Y}$ in Generation Z Period: Management of Different Generations in Business Life". Mediterranean Journal of Social Sciences, 5(19). https://10.5901/mjss. 2014.v5n19p218.

Hasmidyani, D., Fatimah, S., \& Firmansyah, F. (2018). "Mengembangkan Jiwa Kewirausahaan Generasi Muda Melalui Pelatihan Penyusunan Rencana Usaha". MITRA: Jurnal Pemberdayaan Masyarakat, 1(1): 32-47. https://doi. org/10.25170/mitra.v1i1.13

Iswahyudi, M., \& Iqbal, A. (2018). "Minat Generasi Milenial Untuk Berwirausaha". Assets: Jurnal Akuntansi Dan Pendidikan, 7(2): 95. https://doi.org/ 10.25273/jap.v7i2.3320.

Lestari, Wini Widia, et al. (2021). "Productive Workforce: Portrait, Role and Strategy in Bogor Regency". International Journal of Sciences: Basic and Applied Research (IJSBAR), 55(1): 235-246. https://gssrr.org/index. php/JournalOfBasicAndApplied/articl e/view/12209.

Tampubolon, L. R. R., \& Amiq, B. (2017). Model Pelatihan Untuk Menghasilkan Wirausaha Muda Profesional Di Universitas Dr. Soetomo Surabaya. Seminar Nasional Hasil Pengabdian Kepada Masyarakat, (November), 250-254. http://repository.unitomo. ac.id/id/eprint/946.

Susita, D., Mardiyati, U., \& Aminah, H. (2017). "Pelatihan Kewirausahaan Bagi Pelaku Usaha Kecil Dan Binaan Koperasi Di Rumah Susun Sederhana Sewa (Rusunawa) Cipinang Besar Selatan". Jurnal Pemberdayaan Masyarakat Madani (JPMM), 1(1), 58- 
72. https://doi.org/10.21009/jpmm. 001.1.05.

Van Meter, Donald S. \& Van Horn, Carl E. (1975). "The Policy Implementation Process: A Conceptual Framework". Administration and Society, 6(4): 445488. https://doi.org/10.1177/00953 9977500600404.

Yuwono, S., \& Partini. (2008). "Pengaruh Pelatihan Kewirausahaan Terhadap Tumbuhnya Minat Berwirausaha". Jurnal Penelitian Humaniora, 9(2): 119-127. http://hdl.handle.net/ $11617 / 595$.

\section{Skripsi}

Pujiyati, L. (2018). Analisis Strategi Pengembangan Wirausaha Pemuda Dalam Mewujudkan Wirausahawan Mandiri dan Implikasinya Terhadap Ketahanan Ekonomi Keluarga (Studi Pada Anggota BMT Al-Hasanah Cabang Jati Agung Lampung Selatan). Skripsi. http://repository.radenintan. ac.id/id/eprint/5019.

\section{Dokumen}

Badan Pusat Statistik Kabupaten Serang (BPS-Statistics of Serang Regency). (2020). Kabupaten Serang Dalam Angka Serang Regency In Figures 2020. Serang: Badan Pusat Statistik Kabupaten Serang (BPS-Statistics of Serang Regency). 